\title{
Comparing Sustainability to a Good Life and Well-Being: Overlap, Differentiations and Indefinite Overlap
}

\author{
Jerke W. De Vries ${ }^{1}$ \\ ${ }^{1}$ VHL University of Applied Sciences, Velp, the Netherlands \\ Correspondence: Jerke W. De Vries, VHL University of Applied Sciences, Velp, the Netherlands. Tel: \\ 31-6-5350-3396. E-mail: jerkewdevries@gmail.com
}

Received: March 17, 2018

Accepted: June 16, 2018 Online Published: July 29, 2018

doi:10.5539/jsd.v11n4p68

URL: https://doi.org/10.5539/jsd.v11n4p68

\begin{abstract}
In our society, sustainability has emerged as a major concept in our daily lives and activities, e.g. from reducing the environmental impact of our foods to corporate social responsibility in doing business, and social impact of our activities. The original idea of sustainability was to address human development within social, ecological, and economic boundaries. Nowadays, however, sustainability is more and more extended to other areas of our lives, including aspects of a good life and well-being. The aim here was to compare sustainability, a good life, and well-being and determine their overlap, differentiations, and indefinite or undecided overlap when considering the original definitions. Following from the definition of sustainability, a good life, and well-being, I analyze the overlap, differentiations, and indefinite overlap of these concepts. With this comparison, I show that sustainability is clearly adapting to include more aspects of a good life and well-being (approximately $26 \%$ overlap), but is limited to do so from its original definition. I conclude that overlap between concepts exists and by being relatively different they are fundamentally supportive to one another and need to be applied accordingly to further support sustainable development.
\end{abstract}

Keywords: ethics, environmental impact, good life, sustainability, virtues, well-being

\section{Introduction}

\subsection{Sustainability and Society}

Sustainability is a huge theme in our society and is adopted rapidly in a variety of arenas, from governmental institutions to businesses and non-governmental organizations. From the 1970's and 80's of the past century, sustainability became 'the' leading conceptual framework for providing solutions to counteract the negative human impact on the environment. Negative environmental impacts include: climate change, loss of biodiversity, accumulation of (non-degradable) plastic in the environment, and land degradation (Bellard, Bertelsmeier, Leadley, Thuiller, \& Courchamp, 2012; Derraik, 2002; IPCC, 2006; Tilman et al., 2001; Tukker \& Jansen, 2006). Environmental impact has been the main leading factor for sustainability to arise although in recent decades more focus on other issues, such as social injustice and economic development was added to the debate. Social injustice includes, child labor or discrimination whereas economic development may be translated into rising employment rates or access to the privileges of economic growth (Hopwood, Mellor, \& O'Brien, 2005). Sustainability is most commonly defined according to the Brundtland definition of sustainable development (World Commission on Environment and Development, 1987).

\subsection{New Concepts for Sustainability}

Extending from the Brundtland definition, new concepts for sustainability were developed to encompass social and economic issues next to environmental ones. Concepts include the triple bottom line and more recently corporate social responsibility (CSR) (Elkington, 1999; Garriga \& Melé, 2004). The triple bottom line stems from businesses applying the concept of sustainability in their specific context. This approach aims not only to consider economic output as the main deliverable from businesses but also its social and environmental contribution and performance. The triple bottom line further evolved into CSR by including company values, ethical guidelines, and social responsibilities toward, e.g. employees and civil society (Garriga and Melé, 2004). CSR nowadays is regarded as one of the fundamental strategies needed for businesses to survive in the future, i.e. being a 'must have' instead of a 'nice to have'. 


\subsection{A Good Life and Well-Being}

Although previous developments were helpful for defining and applying sustainability, at the same time they also led to a proliferation of definitions and applications. The amount of definitions is estimated to be at least in the hundreds and maybe even more (Vos, 2007). Examples of definitions include, 'the ability to continue a defined behavior indefinitely' (thwink.org, 2017), 'activities that are ecologically sound, socially just, and economically viable' (uwash.edu, 2017) or it may be defined according to its 'environmental footprint' of a product or process (Manfredi, Allacker, Chomkhamsri, Pelletier, \& Maia De Souza, 2012). The magnitude, importance, and complexity of sustainability, therefore, is constantly changing making sustainability a 'relative concept' (Cameron, 2006). Even more so, sustainability is expanding to integrate parts of a 'good life' and 'well-being' (Di Giulio \& Fuchs, 2014; Sarkar \& Shaw, 2017). A good life and well-being, also called subjective well-being, are similar concepts that partly overlap. Here, I consider the good life as defined by virtuous character. Well-being defines specific indicators that are needed for a good life. Aspects of a good life include, virtues and 'good ethics'. Virtues have long been debated to be a central character trait related to 'good morality' of a specific person or group. Aspects of well-being include, social connectedness or worthiness of connection, sense of meaning or purpose, and overall life satisfaction (Brown, 2012; Diener \& Seligman, 2004). Current developments in society require a broader definition of sustainability. As such, sustainability is starting to include virtues and aims to incorporate aspects of well-being, even up to the point where it is starting to border religion and religious rites (Johnston, 2014). To provide insight into the overlap and differentiation of the concept of sustainability, a good life, and well-being an overview is required that addresses the overlap, but also discusses the opportunity of sustainability to include aspects of a good life and well-being.

\subsection{Objective}

Here, I aim to compare sustainability, a good life, and well-being and determine their overlap, differentiations, and indefinite or undecided overlap. By reviewing the original definitions and intentions of sustainable development and comparing it to the definitions of a good life and well-being, I argue that sustainability has adapted to include a good life and well-being, but that these concepts need to be applied alongside each other to enhance the future perspective of sustainable development.

\section{Method}

\subsection{Review of Concepts}

The concepts of sustainable development, well-being, and a good life were reviewed by addressing literature from scientific and non-scientific sources. In this paper, I consider sustainability and sustainable development as similar concepts; the definition will be provided later. Main scientific material originated from reflections on sustainability, sustainability in the business environment and the original documentation from the Brundtland commission. Sources on well-being and a good life originated from research done in past decades and original sources from philosophers in the past hundreds of years. By reviewing the literature, a matrix was made in which I highlighted the relative overlap, differentiations and indefinite overlap of the concepts. I have sought to provide overview of the main historical lines of how these concepts came into being and what their relevance was in terms of the contextual time-frame.

\subsection{Comparing Overlap, Differentiations, and Indefinite Overlap of Concepts}

After review of concepts, indicators of well-being and a good life were collected in an overview. From this overview and the collection of indicators for sustainable development, a matrix was constructed that provides insight in the overlap, differentiations and indefinite overlap of the concepts. Based on the count of the overlapping cells of the matrix a percentage of overlap was determined.

\section{Results}

\subsection{The Concept of Sustainability}

\subsubsection{Brundtland Definition and Further}

In 1976, the Brundtland Commission introduced the definition of sustainable development. The definition was: 'sustainable development is development that meets the needs of the present without compromising the ability of future generations to meet their own needs' (World Commission on Environment and Development, 1987). This definition here is equaled to sustainability and contains two main concepts: 1 . needs, that are defined as the human requirements bound by social and cultural background, and 2. limitations imposed by technological advances and company organization on the environment that limits the possibility to meet these needs (Mebratu, 1998). The definition provides seven imperatives: 1. meeting essential human needs, 2 . conserving and 
enhancing the resource base, i.e. the resources available on earth, 3. reviving growth, 4. changing the quality of growth, 5. ensuring a sustainable level of population, 6. reorienting technology, and 7. managing risk (World Commission on Environment and Development, 1987; Zaccai, 2012). Although broadly defined, this definition provides the opportunity to seek active measures to reduce our impact on the environment. Only later, by initiatives from, e.g., the inter-governmental panel of climate change (IPCC) in Europe, the specific environmental concern about climate change was exerted into measureable indicators. These indicators include emission of greenhouse gases, such as carbon dioxide, nitrous oxide and hydrofluoric carbons leading to climate change (IPCC, 2006). Other environmental indicators used today include: loss of biodiversity, land use and eutrophication of ground and surface waters (Tukker \& Jansen, 2006). Later, indicators were extended towards social and economic aspects (Zaccai, 2012). Through addition of these indicators, the concept evolved into a critical concept that is used to establish our common interest in reducing environmental and social impact alongside economic development.

\subsubsection{Sustainability in the Business Arena}

Businesses have sought to develop their own definition of sustainability for purposes of operationalization and application in strategic decision-making. Sustainability in business is often considered as the continuation or sustaining of the company, not necessarily environmental or social sustainability. In 1994, however, John Elkington developed the definition of the triple bottom line, also known as the triple P or People, Planet and Profit approach (Elkington, 1999) This approach allows for users to apply indicators for each ' $\mathrm{P}$ ' and develop strategies for specific issues within their specific boundaries. Hence, this provides an opportunity to measure and manage sustainability in broader terms of social, economic and ecological aspects and benchmark it to competitors and standards. By including social aspects into the triple bottom line, it encompasses more than the environmental aspects alone.

The business environment also includes moral and ethical guidelines with regard to rights of employees and other stakeholders, previously known as business ethics (Epstein, 1987). Business ethics are a form of applied ethics examining the moral and ethical problems in the business arena. It became common in light of social relevance and the major savings and loans crisis in the financial district in the 80s' and 90s' of the past century. Businesses have sought to include such guidelines in their normative behavior and make it a strategic investment for sustaining future activities. Today, most companies combine sustainable development goals and social and ethical responsibility in the concept of CSR (Garriga \& Melé, 2004). CSR is defined by authors in ways that vary along public policies to governmental regulations, this variation being in its formulation and interpretation (Garriga \& Melé, 2004; Vogel, 1986). A clear CSR strategy is becoming one of the most important approaches demanded by governmental and societal organizations to justify actions taken by businesses.

\subsection{The Concepts of a Good Life and Well-Being}

\subsubsection{History and Definitions of a Good Life}

The concept of a good life has been debated over throughout history. From historical scholars such as Plato, Socrates, and Aristotle to more recent scholars such as Kant and Nietzsche. In early times, Greek scholars considered a good life first and foremost as a life in community and where personal preferences were regarded as what it means to be just. Indeed, they were often debating about the fact that personal opinions and opinions of the group are seemingly contradictory towards a just world. In Socrates' definition, a just person does not only do what is needed in order to maintain a stable environment in the group but is also in control of his own being, i.e. not ruled by his desires (Jones, 2015). Aristotle argued that a life of well-being should aim at contemplation and learning instead of bodily pleasures only (Barnes, 1984). It is a person of virtue. 'Virtue of character' means as much as the dispositions to act in morally right ways in response to similar situation, the habits of behaving and doing what is right (Barnes, 1984; Kemerling, 2011). Modern scholars, such as Nietzsche aimed at stimulating individuals to think for themselves as universal entities and not only to follow the status quo, but live thoughtfully and virtuous (Jones, 2015). Although Nietzsche never mentioned a good life as meaningful, he did appreciate the leisure it gave. Kant was giving thought to virtue and happiness. He wondered if it could be combined without God in the midst of it, but he finally found that it could not be without God in the middle of it all.

Summing up, the main idea of the good life aims at living a life of virtue or having good character. Living virtuous includes character traits, such as, righteousness, integrity, dignity, self-control, and honor. A good life first and foremost encompasses the whole person to become virtuous in character. Virtuousness may affect well-being. 


\subsubsection{Definitions of Well-Being}

There is no common definition of well-being. Although well-being often relates to physical and emotional well-being, I want to introduce a third dimension: spiritual well-being. Therefore, well-being encompasses three dimensions of life: the biological, the physical and the spiritual dimension (Dodge, Daly, Huyton, \& Sanders, 2012; Strawn, 2012). Well-being is not necessarily defined by a 'perfect' or 'good' condition of each dimension, but rather by a state of balance between positive and negative affect (Diener, Suh, Lucas, \& Smith, 1999). Positive affect may include the opportunity for eating and being safe or having peace and experiencing a higher purpose. On the contrary, negative affect may include hunger, unsafe situations, war, and experiencing no purpose. A biblical prescription on well-being and good life is called the greatest commandment: 'love the Lord your God with all your heart and with all your soul and with all your mind and love your neighbor as yourself' (Matthew 22:37-40, New International Version). Hence, well-being targets specific indicators or aspects in the biological, physical, and spiritual realm capturing their positive and negative affect.

\subsubsection{Linking Aspects of a Good Life and Well-Being}

The aspects in Table 1 are part of greater denominators, such as economics (like income equality and height), religion, social capital (like trust, and mutual helpfulness), governance (like trustworthy and faithful governments), and productivity in the work environment (Diener \& Seligman, 2004). These general aspects provide the basis in all dimensions of life. Although a complete analysis of aspects and indicators of a good life and well-being leads to far for the purpose presented here, Table 1 provides a simple overview with main aspects, indicators, and virtues within the three dimensions considered.

Table 1. Aspects of a good life and well-being within three dimensions of life: biological, physical, and spiritual

\begin{tabular}{llcc}
\hline & Dimensions of life & \\
Steps & Biological & Physical & Spiritual \\
\hline 1 & General or contextual aspects: economics, religion, governance, social capital, and work environment
\end{tabular}

2 Basic needs: physiological, safety, love/ belonging, esteem, self-actualization

3 (Self-perceived) health/ Harmony with the environment Transcendental connectedness

mental illness/ longevity

Healthy behaviors $\quad$ Physical illness Meaning or purpose

(Social) connectedness

$4 \quad$ Virtues: hope, love, generosity, forgiveness, honesty, justice, purity, etc.

Based on: (Garriga \& Melé, 2004); (Lyubomirsky, King, \& Diener, 2005); (CDC, 2017); (Tay \& Diener, 2011); (Maslow, 1943); (Jones, 2015); (Barnes, 1984), and (Strawn, 2012).

Biological aspects include (self-perceived) health, mental illness, longevity, healthy behaviors, and (social) connectedness. Health is aimed at the well-functioning of the body. It does not mean a complete lack of illness or death, but the possibility of doing what is needed along with the meaning or purpose in someone's life (Skidelsky \& Skidelsky, 2012). Mental illness is related to a healthy psychological state. Longevity is the expectancy that your life may extend as long as it is expected to do so. Healthy behaviors encompass behaviors that support the well-being of a person and do not degrade it. (Social) connectedness tells a person how well he or she is connected to his or her environment in terms of human interaction (Tay \& Diener, 2011).

Physical aspects include harmony with the environment and physical illness (Garriga and Melé, 2004; Skidelsky and Skidelsky, 2012). Harmony with the environment occurs when people experience or enjoy the esthetical side of nature, but also when understanding is obtained of nature, e.g. by learning how food is produced and what animals live like. Physical illness indicates the limitation someone experiences in the body, e.g., a lame or deaf person.

Spiritual aspects include the experience of transcendental connectedness and a sense of meaning or purpose 
(Strawn, 2012; Tay \& Diener, 2011) Transcendental connectedness is experienced in situations where people receive revelation from outside their own experience. These terms point towards an entity that people relate to as being higher or of another magnitude. Hence, this entity encompasses a sense of connectedness and oneness from which meaning and purpose stem at the same time. Experiencing purpose or meaning is essential for well-being (Diener \& Seligman, 2004).

Virtues encompass the three dimensions of life (Table 1). They include character traits that encompass the whole person or group that resembles the trait and therefore includes more than a single aspect of well-being. E.g. in order to love, one needs at least a basic health (biological dimension), functioning of the body (physical dimension), and a conviction or revelation that to love is the right thing to do (spiritual dimension). A person or group carrying virtues may be a Buddhist monk or a group of Christians. But it may also be a given individual who has no specific religious affiliation. A virtuous character develops along the life in which sometimes well-being may already be achieved, but may as well be lacking or limited. A person with hunger may still be a person of virtue while he or she does not have all privileges of experiencing well-being. The suggested steps in Table 1 imply that life develops along these steps, but this is not necessarily linear. Firstly, the general prerequisites need to be in place, including the aspects mentioned under the good life or well-being in steps 1 and 2. Where step 1 encompasses the more general outline of a group or country, step 2 includes the basic personal or human needs; a concept already clearly developed by Abraham Maslow. As such, these two steps provide the soil for concepts of well-being in step 3. Finally, step 4 includes the virtues that encompass all dimensions.

\section{Discussion}

\subsection{Analysis of Overlap, Differentiations, and Indefinite Overlap of Concepts}

In this section, I will describe the analysis of the overlap, differentiations and indefinite overlap of the presented concepts: sustainability, a good life, and well-being. Table 2 presents an overview of the concepts split out into their respective aspects.

The main overlap of concepts exists in the social aspects. Sustainability encompasses social aspects expressed in the essential human needs and sustainable levels of population. In these social aspects, focus is not only on providing basic human needs but also to enhance the well-being of people. Clearer definition of well-being or a good life within the context of sustainability is, however, yet to be defined. Another overlap is the natural environment. Enhancing the resource base and merging environment and economics in decision making contribute to living in harmony with the environment, an important factor for well-being. Living in harmony with the environment can also be stimulated by changing the quality of growth, i.e. through including environmental indicators together with economic growth. These two developments should go hand in hand.

The main differentiations between the concepts are the preservation of the natural environment (planet), typically used in sustainability, and the social aspects of living (people), typically used in a good life and/ or well-being. Reorienting technology and risk management, therefore, is one aspect of sustainability that links poorly or limited to a good life and well-being. Other differentiations include the essential human needs under sustainable development and basic needs under well-being. Essential human needs include food and employment, whereas basic needs under well-being include the needs as mentioned by Maslow.

The indefinite or undecided overlap of the concepts lies in profit, the quality of growth, and the virtues (Table 2). Changing the quality of growth has to do with the inclusion of environmental aspects together with aspects of a good life and well-being but has been not or poorly identified. Virtues may be in line with the idea of business ethics as a part of social sustainability.

\subsection{Sustainability and the Adapting to a Good Life and Well-Being}

From the analysis presented, it becomes clear that sustainability, a good life, and well-being are originally different concepts. Although overlap occurs (approximately 26\%, 18 green cells divided by 70 cells total, Table 2) clear differentiations (approximately 59\%, 41 blank cells divided by 70 cells total, Table 2 ) are visible. Another part is left indefinite and remains undecided (approximately 16\%, 11 cells divided by 70 cells total, Table 2 ). In the social domain of sustainability most development is taking place to encompass more aspects of a good life and well-being. Developments in the business arena, triggered by the past financial crisis, are again targeted at including virtuousness as one of the central character traits required for strategic development, e.g. (A. Racelis, 2017; A. D. Racelis, 2013). This may induce a new direction for social sustainability and CSR. Hence, sustainability is adapting towards a good life or well-being, but will most likely not replace them. Sustainability is mainly aimed to inform on how we relate to the environment but lacks authority in the other areas of life. Here, 
the concepts of a good life and well-being come into play to support sustainable development. Development that reduces or lacks well-being is per definition unsustainable. Therefore, I expect that these concepts will in the future further be used to reinforce one another.

\subsection{Economics}

The aspect of economics and profit has not been strongly addressed in this study. Money is needed to obtain aspects of a good life or well-being and is an intrinsic pillar in the triple P approach (Elkington, 1999; Skidelsky \& Skidelsky, 2012). One may argue, therefore, that economic development is first and foremost necessary to obtain a good life. Although needed, Diener \& Seligman (2004) already indicated that well-being often leads to desirable economic outcomes and not the other way around. Even more, economic growth only shows a moderate effect on well-being on individual and collective levels. This effect is strong mainly when basic needs are lacking, but remains moderate after these needs are met. Economic development, therefore, is first and foremost based on other capita, such as environmental and social ones. Is it not necessary to first have (natural) resources available and social structures in place before trade and economic development can take place? This idea corresponds with others, e.g. Sogesid (2017) who proposes that the environmental dimension has a fundamental role in supporting economic and even social dimension of sustainability (Sogesid, 2017). Giddings et al. (2002) mentioned that (economic) activities and society are part of the environment, not the other way around (Giddings, Hopwood, \& O'Brien, 2002). Adding to this, economic growth that reduces or lacks well-being is per definition unsustainable. Therefore, the change in quality of growth (Table 2) should encompass indicators for well-being or a good life. Previous research already addressed that indicators for well-being need to be added to national inventory systems, e.g. (Diener \& Seligman, 2004). This supports the idea to increase quality of growth within sustainable development. Summing up, environmental and social capital remain the basis for economic development and growth. Hence, indicators that include environmental and social impact are important to use in normative developments, such as sustainability.

\subsection{Defining Good and Bad, Norms and Values in the Debate}

A good life or well-being and sustainable development both incorporate a normative component, i.e. aspects that are judged good or bad. Think of the good life or well-being and someone having a certain illness. This illness causes someone to be physically limited. The respective person may still be able to do his or her life work, i.e. follow-up on his or her mission, but may be limited in other physical activities. Is this a good or a bad thing? Does this mean the person has a good or a bad life or experiences a greater lack of well-being compared to one without the illness? Maybe, but it may well be that another person will have a different experience of well-being or a good life in the same situation. The way we respond to such situations depends on character traits, norms and values, and the way the person developed over time, e.g. (Fleeson, 2004). Norms and values are in part culturally dependent and change over time as one adapts to his or her circumstances. Similarly, this holds for sustainability. For example, how good or bad is it when a certain part of a forest is cut down and used for wood production? Certainly, this will depend on contextual indicators, such as how much wood has been harvested before or how the social environment depends on the forest. Answering the question of what is good or bad in the context of sustainable development, therefore, often remains a balancing of different indicators, which in course of time may change according to changing context or social factors. This means there is always a certain amount of subjectivity involved in decision-making and analysis of a good life, well-being or sustainability. Diener and colleagues recognized this subjectivity as an inherent part of defining well-being (Diener et al., 1999). This argument strongly relates to the idea of a 'relatively different concepts'.

\subsection{The Relativity of Sustainability, a Good Life, and Well-Being}

Sustainability, a good life, and well-being are concepts that are constantly evolving. By encompassing more of each other makes the concepts into more of the same instead of more different. They can, therefore, only be seen as 'relatively different' (Cameron, 2006). Relatively, because the concepts exist in different degrees depending on the context they are used in. What sustainability truly is, therefore, remains a matter of definition. The definition will always defined according to the users cultural context and boundary conditions. Henceforth, comparing sustainability will also be relative to its definition. Including virtues that encompass all dimensions of life, therefore, are needed to have future outlook. 
Table 2. Comparison of the concept of sustainability and the concept of a good life and well-being

\begin{tabular}{|c|c|c|c|c|c|c|c|c|c|c|c|}
\hline Triple & Aspects of a good life & General or & Basic & (Self- perceived) & Healthy & (Social) & Harmony with & Physical & Transcen- dental & Meaning & Virtues \\
\hline bottom & and well-being (Table & contextual & needs & health/mental & behave-ours & connected- & the environ- & illness & connected-ness & or purpose & \\
\hline \multirow[t]{4}{*}{ line } & 1) $\rightarrow$ & aspects & & illness/ longevity & & ness & ment & & & & \\
\hline & Categories of & & & & & & & & & & \\
\hline & Brundtland & & & & & & & & & & \\
\hline & Meeting essential & & & & & & & & & & \\
\hline People/ & needs & & & & & & & & & & \\
\hline \multirow[t]{5}{*}{ social } & Sustainable levels of & & & & & & & & & & \\
\hline & population & & & & & & & & & & \\
\hline & Reorienting & & & & & & & & & & \\
\hline & technology and risk & & & & & & & & & & \\
\hline & management & & & & & & & & & & \\
\hline Planet/ & Enhancing the & & & & & & & & & & \\
\hline ecolo- & resource base & & & & & & & & & & \\
\hline \multirow[t]{3}{*}{ gical } & Merging environment & & & & & & & & & & \\
\hline & and economics in & & & & & & & & & & \\
\hline & decision making & & & & & & & & & & \\
\hline
\end{tabular}

Reviving growth

Profit/ Changing the quality

econo- of growth

Color code: Green is where concepts overlap and give insight into similar aspects. Orange is where overlap is indefinite. Where cells are left blank, there is a differentiation between concepts.

\subsection{Virtues as the Basis for Well-Being and Sustainability}

Virtues are mentioned in the definition of sustainable development or well-being but are not central to the concepts. It is, however, arguable that enabling virtues will lead to a higher state of well-being, but also a higher level of sustainable development. Virtues encompass the whole person and require internalization of good moral behaviors (Table 1). Hence, these good and moral insights may well be directed towards sustainability, a good life or well-being, i.e. to be externalized. Research has shown that societies with high levels of trust have higher levels of sociability and organizations with virtues including love, trust, and forgiveness are critical for maximizing members contribution and organizational value (Caldwell \& Dixon, 2010; Carr, 2011; Fukuyama, 1995). Previous means that moral values and character development serve as the basis for properly judging the 'outside world'. Emphasis has been on educating moral virtues and character development, e.g. (Carr, 2011), although emphasis has been lacking in sustainability education.

\section{Conclusion}

The aim of this paper was to compare sustainability, a good life, and well-being and determine their overlap, differentiations, and indefinite or undecided overlap. The analysis presented clearly shows there is overlap (+/$26 \%$ ) between sustainability, a good life, and wellbeing and that this overlap is increasing mainly in the social domain of sustainability. Considering the imperatives from the Brundtland definition, a good life and well-being mainly overlap in the fields of: sustainable levels of population, meeting essential needs, merging environment and economics into decision making, enhancing the resource base, and changing the quality of growth. These imperatives mainly overlap with the need to be in harmony with nature for well-being. In businesses, the concept of sustainability, expressed in corporate social responsibility, is clearly advancing to further encompass ethics and virtues in the decision-making processes. I conclude that the original definition of sustainability already evolved to include much broader aspects than its original intent. I also conclude that sustainability needs the 
concepts of well-being and a good life to support and enhance quality of growth in terms of economic and social development. Virtues are an important basis to establish a good life and sustainability. Finally, I conclude that these concepts and indicators, being relatively different, are fundamentally supportive to one another and need to be applied accordingly to guarantee sustainable development.

\section{Acknowledgments}

Lorie Hamelin is gratefully acknowledged for reviewing a preliminary version of this paper.

\section{References}

Barnes, J. (1984). The complete works of Aristotle. Volume 1: the revised Oxford translation. Princeton University Press. Retrieved from http://press.princeton.edu/titles/5967.html

Bellard, C., Bertelsmeier, C., Leadley, P., Thuiller, W., \& Courchamp, F. (2012). Impacts of climate change on the future of biodiversity. Ecology Letters, 15(4), 365-377. https://doi.org/10.1111/j.1461-0248.2011.01736.x

Brown, B. (2012). Daring Greatly: How the Courage to Be Vulnerable Transforms the Way We Live, Love, Parent, and Lead. London, England: Penguin Books. Retrieved from http://www.ingentaconnect.com/search/article?option 1=tka\&value $1=$ brown+daring+greatly\&pageSize $=10$ \&index $=1$

Caldwell, C., \& Dixon, R. D. (2010). Love, Forgiveness, and Trust: Critical Values of the Modern Leader. Journal of Business Ethics, 93(1), 91-101. https://doi.org/10.1007/s10551-009-0184-z

Cameron, W. S. K. (2006). Wilderness in the City. Environmental Philosophy, 3(2), 28-33. https://doi.org/10.5840/envirophil20063215

Carr, D. (2011). Educating the virtues: An essay on the philosophical psychology of moral development and education (Vol. 10). Routledge.

CDC. (2017). Well-Being Concepts. Retrieved July 20, 2017, from https://www.cdc.gov/hrqol/wellbeing.htm

Derraik, J. G. (2002). The pollution of the marine environment by plastic debris: a review. Marine Pollution Bulletin, 44(9), 842-852. https://doi.org/10.1016/S0025-326X(02)00220-5

Di Giulio, A., \& Fuchs, D. (2014). Sustainable consumption corridors: Concept, objections, and responses. Gaia, 23, 184-192. https://doi.org/10.14512/gaia.23.S1.6

Diener, E., \& Seligman, M. E. P. (2004). Beyond Money Toward an Economy of Well-Being. Psychological Science in The Public Interest, 5(1), 1-31. Retrieved from http://www.psychologicalscience.org/pdf/pspi/pspi5_1.pdf

Diener, E., Suh, E. M., Lucas, R. E., \& Smith, H. L. (1999). Subjective well-being: Three decades of progress. Psychological Bulletin. https://doi.org/10.1037/0033-2909.125.2.276

Dodge, R., Daly, A., Huyton, J., \& Sanders, L. (2012). The challenge of defining wellbeing. International Journal of Wellbeing, 2(3), 222-235. https://doi.org/10.5502/ijw.v2i3.4

Elkington, J. (1999). Cannibals with forks: the triple bottom line of 21 st century business. Capstone.

Epstein, E. M. (1987). The Corporate Social Policy Process: Beyond Business Ethics, Corporate Social Responsibility, and Corporate Social Responsiveness. California Management Review, 29(3), 99-114. https://doi.org/10.2307/41165254

Fleeson, W. (2004). Moving Personality Beyond the Person-Situation Debate. Current Directions in Psychological Science, 13(2), 83-87. https://doi.org/10.1111/j.0963-7214.2004.00280.x

Fukuyama, F. (1995). Trust: The social virtues and the creation of prosperity. Free Press Paperbacks.

Garriga, E., \& Melé, D. (2004). Corporate Social Responsibility Theories: Mapping the Territory. Journal of Business Ethics, 53(1/2), 51-71. https://doi.org/10.1787/9789264122352-de

Giddings, B., Hopwood, B., \& O’Brien, G. (2002). Environment, economy and society: fitting them together into sustainable development. Sustainable Development, 10(4), 187-196. https://doi.org/10.1002/sd.199

Hopwood, B., Mellor, M., \& O’Brien, G. (2005). Sustainable development: mapping different approaches. Sustainable Development, 13(1), 38-52. https://doi.org/10.1002/sd.244

IPCC. (2006). 2006 IPCC Guidelines for National Greenhouse Gas Inventories. Retrieved July 10, 2017, from http://www.ipcc-nggip.iges.or.jp/public/2006gl/ 
Johnston, L. F. (2014). Sustainability as a Global Faith? the Religious Dimensions of Sustainability and Personal Risk. Journal of the American Academy of Religion, 82(1), 47-69. https://doi.org/10.1093/jaarel/lft056

Jones, J. (2015). What is the Good Life? Plato, Aristotle, Nietzsche, \& Kant's Ideas in 4 Animated Videos | Open Culture. $\quad$ Retrieved July $\quad 10, \quad 2017, \quad$ from http://www.openculture.com/2015/12/plato-aristotle-nietzsche-kants-ideas-on-the-good-life.html

Kemerling, G. (2011). Aristotle: Ethics and the Virtues. Retrieved July 20, 2017, from http://www.philosophypages.com/hy/2s.htm

Lyubomirsky, S., King, L., \& Diener, E. (2005). The Benefits of Frequent Positive Affect: Does Happiness Lead to Success? Psychological Bulletin, 131(6), 803-855. https://doi.org/10.1037/0033-2909.131.6.803

Manfredi, S., Allacker, K., Chomkhamsri, K., Pelletier, N., \& Maia De Souza, D. (2012). Product Environmental Footprint (PEF) Guide; Consolidated Version. Ispra, Italy. Retrieved from http://ec.europa.eu/environment/eussd/pdf/footprint/PEF methodology final draft.pdf

Maslow, A. H. (1943). A Theory of Human Motivation. Psychological Review, 50, 370-396. Retrieved from http://psychclassics.yorku.ca/Maslow/motivation.htm

Mebratu, D. (1998). Sustainability and Sustainable Development: Historical and. Environment Impact Assessment Review, 98(98), 493-520.

Racelis, A. (2017). The Role of Virtues in Business and Management. I. Virtue Ethics: Historical Background. Retrieved July 22, 2017, from http://www.academia.edu/8326233/_The_Role_of_Virtues_in_Business_and_Management_I._Virtue_Ethic s_Historical_Background

Racelis, A. D. (2013). Developing A Virtue Ethics Scale: Exploratory Survey of Philippine Managers. Asian Journal of Business and Accounting, 6(61). Retrieved from http://repository.um.edu.my/1174/1/2.pdf

Sarkar, R., \& Shaw, A. (2017). Essays on Sustainability and Management: Emerging Perspectives. Retrieved from https://books.google.nl/books?id=fGclDwAAQBAJ\&pg=PA5\&lpg=PA5\&dq=sustainability + cannot + act + as $+\mathrm{a}+$ concept + for $+\mathrm{a}+$ good + life\&source $=$ bl\&ots $=$ tDbi60mO-Q\&sig $=$ AE8WHyNzhRachyxw3LlFsd1 tByk\&hl $=\mathrm{nl} \& \mathrm{sa}=\mathrm{X} \& \mathrm{ved}=0 \mathrm{ahUKEwjz64ur6Z7UAhUGK1AKHYyICE0Q6AEIKTAB \#} \mathrm{v}=$ onepage $\& \mathrm{q} \& \mathrm{f}=$ false

Skidelsky, R., \& Skidelsky, E. (2012). How Much is Enough?: Money and the Good Life. New York: Other Press. Retrieved from https://www.amazon.com/How-Much-Enough-Money-Good-ebook/dp/B005O0ZT3E

Sogesid. (2017). Sustainable development. 1. The evolution of the "Sustainable Development" concept. Retrieved July 25, 2017, from http://www.sogesid.it/english_site/Sustainable_Development.html

Strawn, B. A. (2012). The Bible and the pursuit of happiness: what the Old and New Testaments teach us about the good life. Oxford University Press.

Tay, L., \& Diener, E. (2011). Needs and Subjective Well-Being Around the World. Journal of Personality and Social Psychology, 101(2), 354-365. https://doi.org/10.1037/a0023779

thwink.org. (2017). Definition of Sustainability. Retrieved July 9, 2017, from http://www.thwink.org/sustain/glossary/Sustainability.htm

Tilman, D., Fargione, J., Wolff, B., D\&\#039;Antonio, C., Dobson, A., Howarth, R., ... Swackhamer, D. (2001). Forecasting Agriculturally Driven Global Environmental Change. Science, 292(5515), 281 LP-284. Retrieved from http://science.sciencemag.org/content/292/5515/281.abstract

Tukker, A., \& Jansen, B. (2006). Environmental Impacts of Products: A Detailed Review of Studies. Journal of Industrial Ecology, 10(3), 159-182. https://doi.org/10.1162/jiec.2006.10.3.159

uwash.edu. (2017). Definitions of Sustainability. Retrieved July 9, 2017, from https://www.uwosh.edu/facstaff/barnhill/490-docs/readings/definitions.pdf

Vogel, D. (1986). The study of social issues in management: A critical appraisal. California Management Review, $28(2), 142-151$.

Vos, R. O. (2007). Defining sustainability: a conceptual orientation. Journal of Chemical Technology \& Biotechnology, 82(4), 334-339. https://doi.org/10.1002/jctb.1675

World Commission on Environment and Development. (1987). Report of the World Commission on Environment and Development: Our Common Future. Oslo. Retrieved from 
http://www.un-documents.net/our-common-future.pdf

Zaccai, E. (2012). Over two decades in pursuit of sustainable development: Influence, transformations, limits. Environmental Development, 1(1), 79-90. https://doi.org/10.1016/j.envdev.2011.11.002

\section{Copyrights}

Copyright for this article is retained by the author(s), with first publication rights granted to the journal.

This is an open-access article distributed under the terms and conditions of the Creative Commons Attribution license (http://creativecommons.org/licenses/by/4.0/). 